\title{
THE NEOTROPICAL ORBWEAVERS OF THE GENUS LARINIA (ARANEAE: ARANEIDAE)*
}

\author{
By Jonathan C. Harrod, Herbert W. Levi and \\ LAURA B. LEIBENSPERGER \\ Harvard College and Museum of Comparative Zoology, \\ Harvard University, Cambridge, Mass. 02138
}

This paper is one in a series of publications on Neotropical orbweavers (Levi 1968, 1971, 1985, 1986, 1988, 1989a, 1989b, in press), made to facilitate identification of common American spiders. It is hoped that this information will also contribute to our knowledge of the phylogeny and relationships of orb-weaving spiders.

Larinia consists of 30 to 40 species, the genus having world-wide distribution. In the 1970s, Grasshoff (1970a, b, c, 1971) revised the African and Indoaustralian species of Larinia, placing them into nine genera. Genera were distinguished by details of palpal structure, especially of the radix, (a projection of the tegulum, illustrated here in Fig. 41). Grasshoff (1971) placed the American species Larinia directa in the genus Drexelia, this genus being distinguished by the internal structure of the epigynum: ducts that are wide on the outside and narrow toward the seminal receptacles (Levi 1975, fig. 9, 12). Levy (1986) also used Grasshoff's genera in revising Larinia of Israel. Alternatively, Levi (1975), revising the Larinia of North America, placed all species in Larinia, as did Marusik (1986), with Larinia of the USSR and Tanikawa (1989), with Larinia of Japan. In the current paper, we use Larinia in this broad sense, including the nine genera into which Grasshoff split the genus. We do not follow Grasshoff, partly because of the difficulty in placing our species known only from one sex into his genera. Operationally, we consider Grasshoff's genera to be species groups.

Larinia has several synapomorphic characters, including an elongate abdomen, (in a family whose species usually have a spherical abdomen), the anterior median tubercle-like point of the abdomen, a white median ventral streak (also found in the unrelated araneid genera Eustala and Metepeira), and the structure of the epigyna and palpi (see below).

*Manuscript received by the editor August 24, 1990. 
Levi (1975) revised and illustrated the three North American species of Larinia: L. directa (Hentz), L. borealis Banks and L. famulatoria (Keyserling). All three are found in Mexico; L. directa is also found throughout the Neotropics. This paper includes the nine species found in the West Indies and south of Mexico.

Materials and Methods. Methods are similar to those described in previous papers. Levi (1977) includes a description of the working method, which will also be discussed in a forthcoming revision of the genus Wixia.

Eye sizes were described using the diameter of the anterior median eyes as a standard. For the anterior eye row, distance between eyes was measured in number of anterior median eye diameters; for the posterior eye row, in number of posterior median eye diameters.

We thank the curators of the following collections for the loan of specimens:

AMNH American Museum of Natural History, New York; N. Platnick, L. Sorkin

BMNH British Museum (Natural History), London, England; P. Hillyard

CAS California Academy of Sciences, San Francisco; W. J. Pulawski, D. Ubick

IRSNB Institut Royal des Sciences Naturelles de Belgique, Brussels, Belgium; L. Baert

MACN Museo Argentino de Ciencias Naturales, Buenos Aires, Argentina; E. A. Maury

MAES J. M. Maes, León, Nicaragua

MBUCV Museo de Biologia, Universidad Central, Caracas, Venezuela; J. Racenis

MCN Museu de Ciências Naturais, Porto Alegre, Brazil; A. Lise, E. Buckup

MCZ Museum of Comparative Zoology, Cambridge, Mass.

MEG M. E. Galiano, Buenos Aires, Argentina

MIUP Museo de Invertebrados, Universidad de Panamá, Panama; D. Quintero A.

MLP Museo de Universidad Nacional, La Plata, Argentina; R. F. Arrozpide

MNHN Museum National d'Histoire Naturelle, Paris, France; J. Heurtault 
MHNSM Museo de Historia Natural, Universidad Nacional Mayor de San Marcos, Lima, Peru; D. Silva D.

MNRJ Museu Nacional, Rio de Janeiro, Brazil; A. Timotheo da Costa

MZSP Museu de Zoologia da Universidade de São Paulo, Brazil; P. Vanzolini, L. Neme, J. L. M. Leme

NRMS Naturhistoriska Riksmuseet, Stockholm, Sweden; T. Kronestedt

SMF Forschungsinstitut Senckenberg, Frankfurt, West Germany; M. Grasshoff

USNM National Museum of Natural History, Smithsonian Institution, Washington, D.C.; J. Coddington

ZMK Zoologisk Museum, K $\phi$ benhavn, Denmark; H. Enghoff

Research was started with the support of National Science Foundation grant GB-36161.

We also thank E. Buckup, who identified a number of specimens in the MCN collection for us, using our preliminary drawings. $P$. Sierwald read the manuscript and made numerous valuable suggestions. D. Silva D. was helpful in locating a Peruvian place name.

\section{Larinia Simon}

Larinia Simon, 1874: 115. Type species by monotypy Epeira lineata Lucas, 1846 . The gender of the generic name is feminine. Levi, 1975: 102.

Drexelia McCook, 1892: 127. Type species by monotypy Epeira directa Hentz (1847).

Diagnosis. Larinia differs from the related genus Araneus by the elongate, oval abdomen, often with an anterior, median tubercle (Figs. 3, 8, 12, 18, 28, 38, 45) and sometimes projecting behind and above the spinnerets (Figs. 19, 23, 29). The abdomen usually has a dorsal pattern of longitudinal marks (Figs. 3, 8, 12, 18, 22, 28, 34, 38,45 ), and venter with median white markings on black (Figs. 4, 9 , $13,19,23,29,35,39$ ).

Eustala fuscovittata and some other Eustala resemble Larinia in shape and markings. However, the genitalia differ: female Eustala have a scape that projects anteriorly from the base, and males have a white colored, lightly sclerotized, cone shaped median apophysis. The resemblance in shape and markings is a homoplasy.

Description. The light colored carapace may have a double, black, longitudinal line behind the eyes that fuses into a single median longitudinal line (Figs. 12, 18, 28, 45). The sternum may be 
all black (in L. ambo and L. lampa), all yellow (in L. bivittata, $L$. directa, and L.t-notata), or yellow in the center and darker around the edges ( $L$. minor, L. montecarlo, L. neblina, and L. tucuman). The legs and dorsum of the abdomen are usually light yelloworange. The anterior median eyes are the largest, usually separated by a diameter or more. The posterior medians may be slightly smaller, are separated by their diameter at most, and are often in contact. The ocular quadrangle is narrower behind than in front.

Males have a tooth on the lateral margin of each endite, lack the hook on the first coxae which is found in some araneid genera, and have two macrosetae on each palpal patella (Levi 1975, Fig. 3). The second tibia is thicker than the first.

Genitalia. The epigynum is lightly sclerotized, and has a wrinkled scape enclosing a pocket, with a lip at its tip (Figs. 1, 6, 10). The lip and pocket are synapomorphies shared with Araneus. An exception is L. montecarlo (Fig. 43), but here the scape may have been torn off in all available specimens. The internal female genitalia were illustrated in a previous paper (Levi 1975). The epigynum frequently contains one or two broken embolus tips from a male palpus, which are difficult to remove (Fig. 27, right side; Figs. 32, 33 , on both sides in depressions).

Structure of the palpus is similar to that of Araneus and Nuctenea. The conductor sits on the rim of the tegulum and there is no paramedian apophysis, (this is usually true of genera with the conductor in this position). It is not known whether this condition is primitive or secondary. The presence of two palpal patellar setae is shared with Araneus, Nuctenea and Neoscona.

The palpal embolus is heavily sclerotized. In L. directa, it is a diagonal rod (Fig. 5); in L. montecarlo, a horizontal curved rod (Fig. 47). It is triangular in L. tucuman (Fig. 14), anchor-shaped in L. bivittata (Fig. 24), and comma-shaped in L. ambo (Fig. 30). In $L$. $t$-notata it is hidden behind a lamella (Figs 40,42). In all species, the tip of the embolus rests on the lightly sclerotized conductor (Figs. 5, $14,24,30,47)$. The conductor is attached to the rim of the tegulum as a white irregularly shaped cushion (as it is in Araneus, Levi in press, fig. 3) in L. tucuman (Fig. 15), L. bivittata (Fig. 25), L. ambo (Fig. 31), and L. montecarlo (Fig. 48).

The most visible structure of the palpus is the median apophysis, lying proximally to the embolus. In L. directa, (Fig. 5), L. tucuman 
(Fig. 14), and L. ambo (Fig. 30), the median apophysis has a distal, sclerotized spine and a basal projection which is blunt and less heavily sclerotized. In L. bivittata (Figs. 24, 25), and L. montecarlo (Figs. 47,48 ), the median apophysis has two spines. In L. $t$-notata, the median apophysis is flattened (Fig. 40) with a distal serrated edge (Figs. 41, 42) and a large proximal, pointed, curved prong (Figs. 41, 42). The tegulum of this species also has a flat projection with a serrated edge (right side, Figs. 40, 41, 42).

Distal to the embolus are structures which are difficult to homologize, the terminal and subterminal apophyses. In $L$. directa, the terminal apophysis is triangular and pointed (Fig. 5). In L. tucuman, it appears as a "hanging" rod (Fig. 14). In L. bivittata, both the subterminal and terminal apophyses are pointed "above" the embolus (Fig. 24). In L. ambo, they are pointed and almost parallel to the embolus (Fig. 30). In L. neblina, they are two blunt sclerites (Fig. 40, 42). In L. montecarlo, there are two pointed structures, one pointing "up" and the other "down" (Fig. 47). In all cases, there is a hematodocha between the embolus and the sclerotized portions of the subterminal and terminal apophyses. This is small in L. t-notata (Fig. 42).

Distribution. The genus is found world-wide. There are between 30 and 40 species.

Natural History. Specimens are commonly collected by sweeping vegetation. Larinia directa sits in the hub of the web at night, on vegetation to the side of the web in daytime (Levi 1975).

\section{UnRecognizable Species}

Drexelia scriba Mello-Leitão, 1940: 203 from Colatina, Espírito Santo, Brazil, in MNRJ, lost.

\section{Misplaced SPecies}

Larinia albosigillata Mello-Leitão, 1947b: 247, is an immature Araneus.

Larinia bristowei Mello-Leitão, 1940: 180, belongs in a new genus.

Larinia coamensis Petrunkevitch, 1930: 335, figs. 221-224, + , is Metazygia crewi (Banks). NEW SYNONYMY

Larinia maulliniana Mello-Leitão, 1951: 331 is Zygella x-notata. 
Synonymized by Levi (1974: 276).

Larinia mundula (Keyserling), 1892: 179 is a Metazygia.

Larinia mundulella (Strand), 1916: 114 is a Metazygia.

Larinia nobilis Mello-Leitão, 1944: 331 is Araneus corporosus (Keyserling). Synonymized by Levi (in press).

Larinia rubroguttulata Keyserling, 1880: 314 is a Eustala. Larinia silvestris Bryant, 1942: 5 is a Cyclosa.

Key to Larinia species, females

1 Epigynum with scape; venter of abdomen with black or gray markings. ........................... 2

- Epigynum without scape, as in Figs. 43, 44; venter of abdomen without black or gray markings (Fig. 46); southern Brazil

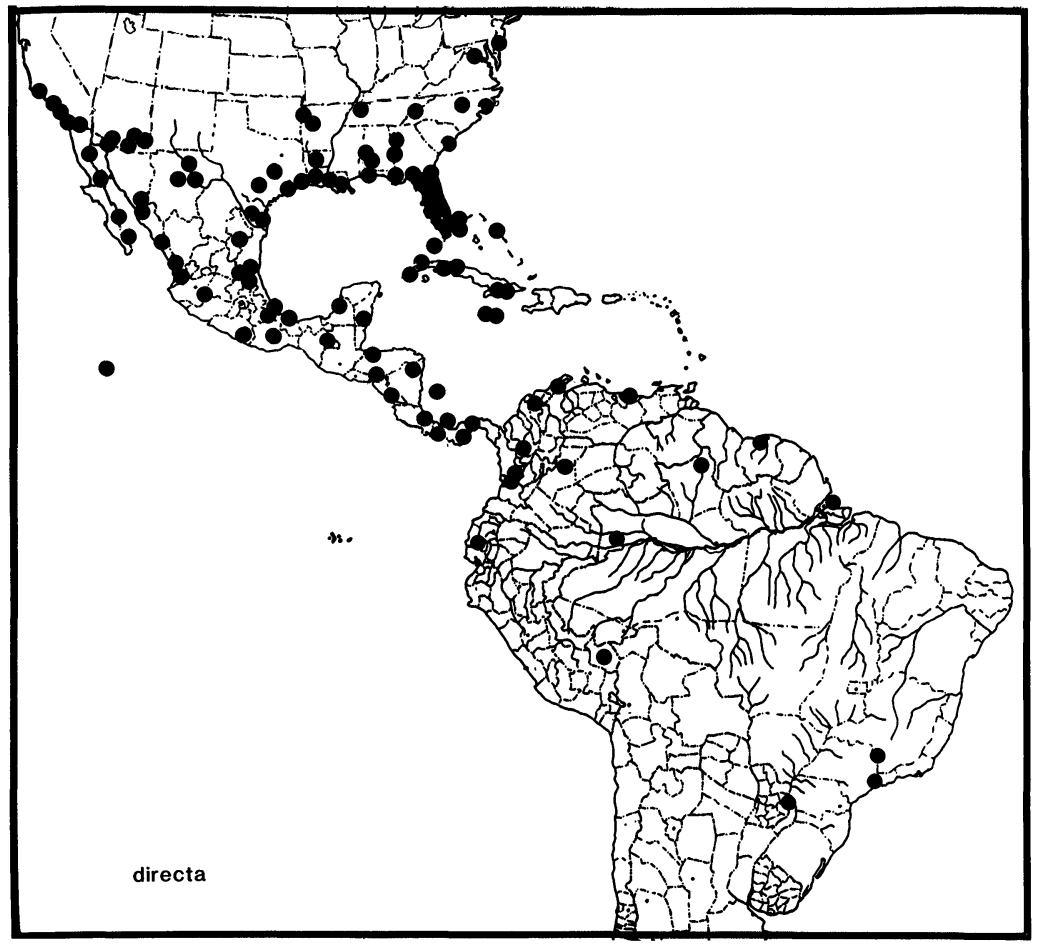

Map 1. Distribution of Larinia directa. 
(Map 2). montecarlo

2(1) Scape longer than broad (Fig. 32, 36). ........... 3

- Scape about as broad as long, or broader than long (Figs. 1, 6, $10,16,20,26) \ldots \ldots \ldots \ldots \ldots \ldots \ldots \ldots \ldots \ldots \ldots .4$

3(2) Abdomen more than twice as long as wide, with prominent anterior median tubercle; dorsum lightly colored, sometimes with a double row of black spots; epigynum as in Figs. 36, 37, with scape often curving to one side; total length greater than $6.0 \mathrm{~mm}$; southern Brazil, Argentina (Map 2). .... t-notata Abdomen with length about one and one half width, rounded, without prominent tubercle; dorsum of abdomen with broad brown bands (Fig. 34); epigynum as in Figs. 32, 33; total length usually less than $6.0 \mathrm{~mm}$; Venezuela (Map 2). ......

neblina

4(2) Abdomen more than twice as long as wide (Figs. 3, 18). . . 5 Abdomen less than twice as long as wide (Figs. 8, 12, 22, 28). ............................. 6

5(4) Distal lip of epigynal scape wide (Fig. 1); total length greater than $6.0 \mathrm{~mm}$; widespread (Map 1).

directa

- $\quad$ Scape with narrow lip (Fig. 16); total length usually less than $6.0 \mathrm{~mm}$; Greater Antilles (Map 2). ............ minor

6(4) Dorsum of abdomen with a pair of dark lateral stripes, straight or undulating, sometimes with a thin median stripe between them (Figs. 8, 12, 22); epigynum as in Figs. 6, 10,

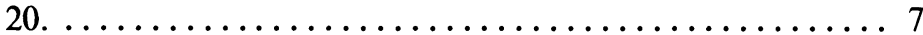

Dorsum of abdomen with a single dark toothed median band (Fig. 28); epigynum as in Fig. 26, 27; Peru (Map 2). .......

ambo

7(6) Edges of lateral dorsal bands undulating (Figs. 12, 22). . . 8

- Lateral bands with straight edges and filled with red-brown dots; epigynum as in Fig. 6; Peru (Map 2). ........ lampa

8(7) Total length less than $4.7 \mathrm{~mm}$; dorsal bands light anteriorly, becoming darker towards posterior; pronounced median notch in posterior lip of epigynal base (Fig. 11); Argentina (Map 2)........................ tucuman

- Total length greater than $5.2 \mathrm{~mm}$; dorsal bands dark throughout entire length. Posterior lip of epigynal base dark, swollen, and sclerotized (Fig. 21); southern Brazil, Chile to Argentina (Map 2).......................... bivittata 
Key to Larinia species, males

1 Palp with both tegulum and median apophysis darkened and with serrated borders, as in Figs. 40-42; total length greater than $5.3 \mathrm{~mm}$; southern Brazil to Argentina (Map 2). ....... ............................. thotata

- Tegulum and median apophysis without serrated borders; total length less than $5.3 \mathrm{~mm} . \ldots \ldots \ldots \ldots \ldots \ldots \ldots 2$

2(1) Embolus triangular (Fig. 14), anchor-shaped (Fig. 24), or comma-shaped (Fig. 30). Abdomen less than twice as long as wide. ............................... 3

- Embolus thin and tubular as in Figs. 5, 47. Abdomen more than twice as long as wide. .................. 5

3(2) Embolus comma-shaped; palpus as in Figs. 30, 31; dorsum of abdomen with a single dark toothed median band; Peru (Map 2). .............................mbo

- Embolus anchor-shaped (Fig. 24) or triangular (Fig. 14); dorsum of abdomen with a pair of dark lateral stripes separated by a thin white median band. ................ 4

4(3) Embolus anchor-shaped, dark, and sclerotized; terminal apophysis with two distinct tips (Fig. 24); dark dorsal bands running entire length of abdomen; southern Brazil, Chile to Argentina (Map 2). .................... bivittata

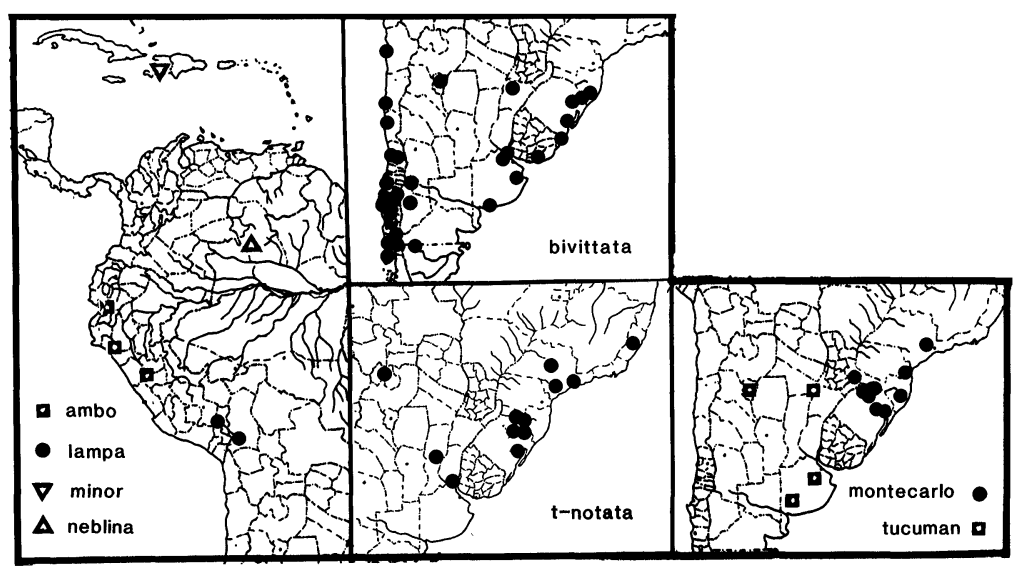

Map 2. Distribution of Larinia species. 
- Embolus triangular, not sclerotized; two tips of terminal apophysis not distinct; palp as in Figs. 14, 15; dorsal bands light or absent anteriorally, becoming darker towards posterior; Argentina (Map 2). ................ tucuman

5(2) Median and terminal apophyses as in Fig. 5; tubular embolus lying diagonal to main axis of palp; usually greater than 4.3 $\mathrm{mm}$ in total length; widespread (Map 1). ........ directa

- Median and terminal apophyses as in Fig. 47; with tubular embolus bending "down;" usually less than $4.3 \mathrm{~mm}$ in length; southern Brazil (Map 2). ............ montecarlo

\section{Larinia directa (Hentz) \\ Figures 1-5; Map 1}

Epeira directa Hentz, 1847: 478, pl. 31, fig. 21, ․ Type specimens from South Carolina and Alabama, destroyed.

Epeira tetragnathoides O.P.-Cambridge, 1889: 16, pl. 7, figs. 9, 10, 오, $\widehat{\sigma}$. Male and female syntypes from Guatemala and Panama, in BMNH. Name preoccupied by Epeira tetragnathoides Walckenaer.

Epeira intercisa O.P.-Cambridge, 1889: 18, pl. 5, fig. 11, §ิ. Male holotype from Bugaba, Panama, in BMNH, lost. First synonymized by F.P.-Cambridge, 1903.

Drexelia directa: - McCook, 1892: 127. F.P.-Cambridge, 1903: 461, pl. 43, figs. 12, 13, ㅇ, ô. Grasshoff, 1971: 93, fig. 45, ㅇ.

Epeira deludens Keyserling, 1893: 261, pl. 13, fig. 195, $\uparrow$, §. Syntypes from Florida and Guatemala, in USNM, examined. First synonymized by F.P.-Cambridge, 1903.

Larinia bellona Banks, 1898: 257, pl. 15, fig. 6, ㅇ, §. Syntypes from Tepic, Mexico, in MCZ, examined. First synonymized by Levi, 1975.

Larinia directa: - Comstock, 1913: 508, fig. 545. Levi, 1975: 105, figs. 1-12, 31, 34, 37-41, ㅇ, ô, Map 1.

Larinia cymotypa Chamberlin, 1924: 649, fig. 93, ㅇ. Female holotype from Gulf of California, in CAS, examined. First synonymized by Levi, 1975.

Larinia albonigra Franganillo, 1934: 158, $\widehat{\jmath}$. Male holotype from Cuba, in Cuban Acad. Sci. First synonymized by Levi, 1975.

Drexelia octopunctata di Caporiacco, 1955: 349, o. Female holotype from Caracas, in MBUCV, examined. First synonymized by Levi, 1975.

Larinia nigrovittata Mello-Leitão, 1947a: 12, figs. 26, 27, $\hat{0}$. Male holotype from Carmo do Rio Claro, Minas Gerais, Brazil, in MNRJ, examined. First synonymized by Levi, 1975.

Description. Female from Veracruz, Mexico. Carapace, chelicerae, endites, coxae, sternum, legs yellow. Carapace with orange longitudinal stripe; sternum with gray border. Labium brown. Dorsum of abdomen with white median stripe, bordered by faint gray 
bands with four black dots along their lateral margins (Fig. 3); venter with median white stripe bordered laterally by black bands (Fig. 4). Posterior median eyes 0.8 diameters of anterior medians, laterals 0.8 diameters. Anterior median eyes 1.3 diameters apart. Posterior median eyes 0.2 diameters apart. Abdomen oval, more than twice as long as wide, with anterior median tubercle (Fig. 3). Total length $7.4 \mathrm{~mm}$. Carapace $2.7 \mathrm{~mm}$ long, 1.5 wide. First femur $3.2 \mathrm{~mm}$, patella and tibia 4.4, metatarsus 4.0 , tarsus 1.4 . Second patella and tibia $4.0 \mathrm{~mm}$, third 2.1, fourth 3.8 .

Male from Veracruz. Color as in female. Posterior median eyes 0.7 diameters of anterior medians, anterior laterals 0.5 diameters, posterior laterals 0.6. Anterior median eyes 1.2 diameters apart. Posterior median eyes in contact with each other. Abdomen oval. Total length $5.2 \mathrm{~mm}$. Carapace $1.9 \mathrm{~mm}$ long, 1.5 wide. First femur $3.2 \mathrm{~mm}$, patella and tibia 4.7, metatarsus 4.9, tarsus 1.5 . Second patella and tibia $4.2 \mathrm{~mm}$, third 1.9 , fourth 3.5 .

Illustration. Specimens from Surinam were illustrated.

Variation. Females varied between 6.2 and $10.5 \mathrm{~mm}$ in length. Males varied between 4.2 and $5.2 \mathrm{~mm}$.

Diagnosis. Larinia directa differs from other species south of Mexico in the wide distal lip on the epigynal scape (Fig. 1) and the tubular embolus lying diagonal to the main axis of the palp (Fig. 5). In Mexico two similar species are found: Larinia famulatoria (Keyserling) and $L$. borealis Banks. Both are illustrated and keyed out by Levi (1975).

Distribution. Southern United States through Paraguay.

Records. United States localities shown are from Levi (1975, Map 1). MEXICO Baja California: La Ribera (CAS); San Felipe (AMNH); Santa Anita (CAS). Islas Revillasgegidos: Isla Socorro (CAS). Sonora: $16 \mathrm{~km} \mathrm{~W}$ of Alamos; $24 \mathrm{~km} \mathrm{~W}$ of Agiabampo; 32 km SW of Sonoyta (all AMNH). Sinaloa: Elota (AMNH). Nuevo León: Linares (AMNH). Tamaulipas: Mante (AMNH). San Luis Potosi: $1.6 \mathrm{~km} \mathrm{SW}$ of Tamazunchale; Valles (both AMNH); $3 \mathrm{~km} \mathrm{~S}$ of Valles (MCZ). Nayarit: Acaponeta; Rio Las Cañyas, $5 \mathrm{~km} \mathrm{NW}$ Acaponeta; Jalisco; Mecatán; Rosamorada; $42 \mathrm{~km} \mathrm{~S}$ of Rosamorada; Tepic (all AMNH). Jalisco: near Anonas (AMNH). Hidalgo: Chapulhuacán (AMNH); Tzindejeh (CAS). Veracruz: Catameco (Playa Azul); Fortín; Veracruz (all AMNH). Michoacan: Jiquilpan; $4.8 \mathrm{~km} \mathrm{~W}$ of Quiroga (both AMNH). Guerrero: $11 \mathrm{~km} \mathrm{~S}$ of Chil- 

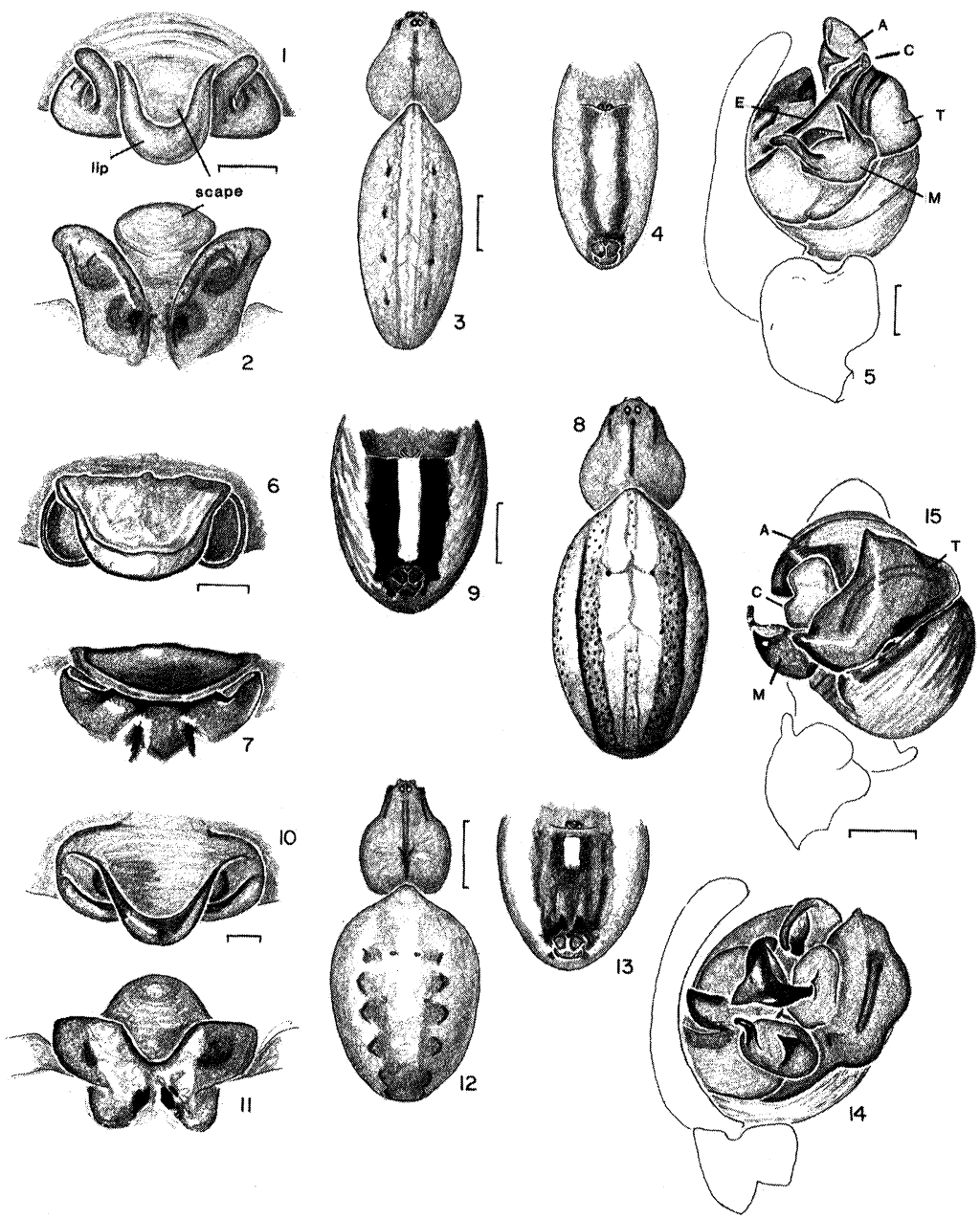

Figures 1-5, Larinia directa (Hentz). 1-4, female. 1, epigynum, ventral. 2, epigynum, posterior. 3, dorsal. 4, abdomen, ventral. 5, male, left palpus, mesal.

Figures 6-9, Larinia lampa n. sp., female. 6, epigynum, ventral. 7, epigynum, posterior. 8, dorsal. 9, abdomen, ventral.

Figures 10-15, Larinia tucuman n. sp. 10-13, female. 10, epigynum, ventral. 11, epigynum, posterior. 12 , dorsal. 13 , abdomen, ventral. 14, 15, male. 14, palpus, mesal. 15, palpus, ventral. Scale lines, $1.0 \mathrm{~mm}$, genitalia $0.1 \mathrm{~mm}$. Abbreviations. A, terminal apophysis; $C$, conductor; E, embolus; $M$, median apophysis; $T$, tegulum. 
pancingo (AMNH). Oaxaca: Oaxaca (AMNH). Chiapas: $105 \mathrm{~km}$ SE of Palenque (MCZ). Quintana Roo: Chetumal (MCZ). HONDURAS Morazán: $27 \mathrm{~km} \mathrm{~S}$ of Tegucigalpa (MCZ). Atlántida: Lancetilla (MCZ). NICARAGUA Corn Island (MCZ); Masawas, Huaspuc River (AMNH); Islas de Solentiname (MAES); León (MAES). COSTA RICA Cartago: Turrialba (CAS, MCZ). Heredia: Puerto Vieja (MCZ). Puntarenas: Monteverde Community (MCZ). PANAMA Bocas del Toro: (MIUP). Canal Zone: Fort Kobbe (AMNH). Chiriquí: Fortuna (MIUP). Panamá: Soberania Natl. Park (MIUP). BAHAMAS common (AMNH). CUBA Real Cambina: Aguada, Las Villas (AMNH). Santa Clara: Topes de Collantes (AMNH). Soledad: Cienfuegos (MCZ). JAMAICA Grove Place; Long Mt.; Lucea (all AMNH). COLOMBIA Antioquia: La Estrella; Medellin (both MCZ). Cesar: Curumaní (AMNH). Magdalena: Santa Marta (SMF). Meta: Carimagua (MCZ). Valle: Río Tuluá; Cali (both MCZ). SURINAM Matapica Beach (AMNH). VENEZUELA Zulia: Rosario (AMNH). ECUADOR Los Ríos: Zapotal (CAS). PERU Madre de Dios: Alto Madre de Dios (MHNSM). BRAZIL Rio Branco: Roraima (MZSP). Amapá: Santana (MEG). Amazonas: Ilha da Marchantario-Rio Solimões (MCN). São Paulo: Guarujá (AMNH). PARAGUAY Alto Paraná: Taquarazapa (AMNH).

\section{Larinia lampa new species}

Figures 6-9; Map 2

Holotype. Female holotype and paratype from $10 \mathrm{~km} \mathrm{~N}$ of Lampa, Quebrada Metara, Depto. Puno, Peru, 3900 m., 31 March to 3 April 1987 (O. Karsholt), in ZMK. The specific name is a noun in apposition after the type locality.

Description. Female holotype. Carapace yellow with thin black median stripe. Chelicerae, coxae yellow, legs yellow with brown spots. Labium yellow anteriorly, brown posteriorly. Chelicerae yellow medially, brown posteriorly. Sternum black. Dorsum of abdomen white with a thin median band and two wider straight lateral bands filled with small red spots (Fig. 8); venter with long straight white band, bordered laterally by dark brown bands (Fig. 9). Posterior median eyes same diameter as anterior medians, laterals 0.8 diameter. Anterior median eyes two diameters apart. Posterior median eyes 1.5 diameters apart. Abdomen oval, a little more than 
1.5 times as long as wide, with anterior median tubercle. Total length $6.2 \mathrm{~mm}$. Carapace $2.8 \mathrm{~mm}$ long, 1.7 wide. First femur 2.7 $\mathrm{mm}$, patella and tibia 2.1 , metatarsus 2.0 , tarsus 0.7 . Second patella and tibia $2.3 \mathrm{~mm}$, third 1.2 , fourth 2.2

Illustration. The holotype was illustrated.

Variation. The specimens ranged from 5.8 to $6.5 \mathrm{~mm}$ in length.

Diagnosis. This species differs from others in the ventral white band from epigynum to spinnerets (Fig. 9), the wide scape of the epigynum (Fig. 6), and the convex ventral margin of the posterior face of the epigynum (Fig. 7).

Paratypes. BOLIVIA La Paz: Tiahuanaco, Puma Puerto Ruins, 1 Feb. 1973, 2q (A. Moreton, MCZ).

\section{Larinia tucuman new species}

Figures 10-15; Map 2

Holotype. Female holotype and male paratype from $30 \mathrm{~km}$ south of Concepción, Tucumán Province, Argentina, 16 January 1983 (L. Peña), in AMNH. The specific name is a noun in apposition after the type locality.

Description. Female holotype. Carapace yellow with brown median line. Chelicerae, coxae, legs yellow. Labium yellow anteriorly, black posteriorly. Endites black laterally, yellow medially. Sternum black with central yellow patch. Dorsum of abdomen white, with a pair of toothed gray longitudinal bands which become more distinct laterally and posteriorly (Fig. 12); venter with small central white patch enclosed by gray lines (Fig. 13). Posterior median eyes same diameter as anterior medians, laterals 0.7 diameter. Anterior median eyes 1.5 diameter apart. Posterior median eyes 0.5 diameter apart. Abdomen oval, less than 1.5 times as long as wide, with anterior median tubercle (Fig. 12). Total length $4.8 \mathrm{~mm}$. Carapace $2.1 \mathrm{~mm}$ long, 1.5 wide. First femur $2.1 \mathrm{~mm}$, patella and tibia 2.6, metatarsus 1.8, tarsus 0.7 . Second patella and tibia 2.1 $\mathrm{mm}$, third 1.2 , fourth 1.7 .

Male paratype. Color as in female, but with much lighter pigmentation. Posterior median eyes 0.8 diameter of anterior medians, anterior laterals 0.8 diameters, posterior laterals 0.8 . Anterior median eyes 1.5 diameters apart. Posterior median eyes 0.5 diameter apart. Abdomen similar in shape to that of female. Total length 3.0 $\mathrm{mm}$. Carapace $1.3 \mathrm{~mm}$ long, 1.0 wide. First femur $2.0 \mathrm{~mm}$, patella 
and tibia 2.0 , metatarsus 1.9 , tarsus 0.8 . Second patella and tibia 1.9 $\mathrm{mm}$, third 1.0, fourth 1.9.

Illustration. The holotype and a paratype from the type locality are illustrated.

Diagnosis. Unlike other species, the posterior plate of the epigynum has a ventral notch (Fig. 11), and the embolus of the palpus is triangular in shape (Fig. 14).

Note. Males and females have been collected together.

Variation. Observed females varied between 3.7 and $4.7 \mathrm{~mm}$ in length.

Paratypes. ARGENTINA Tucumán: $30 \mathrm{~km} \mathrm{~S}$ of Concepción,

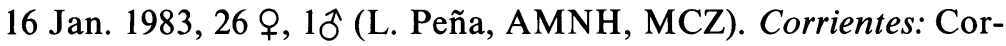
rientes, Jan. 1949, 49 (J. Lieberman, MACN). Buenos Aires: Capilla del Señor, 23 Jan. 1942, 4ð̊ (Prosen, MLP); Sierra de la Ventana, March 1939, 3 ( H. Bavio, MACN).

\section{Larinia minor (Bryant)}

Figures 16-19; Map 2

Drexelia minor Bryant, 1945: 367, fig. 10, ㅇ. Female holotype from Port au Prince, Haiti, July 1941, in MCZ, examined. Brignoli, 1983: 267.

Description. Female holotype. Carapace yellow with a narrow median longitudinal dark band which is double behind the posterior median eyes and fuses to a single line; black line around margin. Sternum with a black band on each side, fusing behind in a black V. Legs yellow with black spots on underside. Dorsum of abdomen with longitudinal white and black bands. The dark bands are darkest on the margin towards the white (Fig. 18). Venter black, enclosing a median longitudinal white mark (Fig. 19). Posterior median eyes 0.7 diameters of anterior medians. Laterals subequal to posterior median eyes, anterior median eyes 1.3 diameters apart. Posterior median eyes 0.3 diameters apart. Abdomen oval, more than twice as long as wide, with anterior median tubercle (Fig. 18). Total length $5.5 \mathrm{~mm}$. Carapace $2.0 \mathrm{~mm}$ long, 1.4 wide. First femur 2.6 $\mathrm{mm}$, patella and tibia 3.7 , metatarsus 3.4 , tarsus 1.3 . Second patella and tibia $3.3 \mathrm{~mm}$, third missing, fourth 1.7 .

Diagnosis. This species differs from all others by two large lateral plates with a convex median border as seen in the posterior view of the epigynum (Fig. 17). 


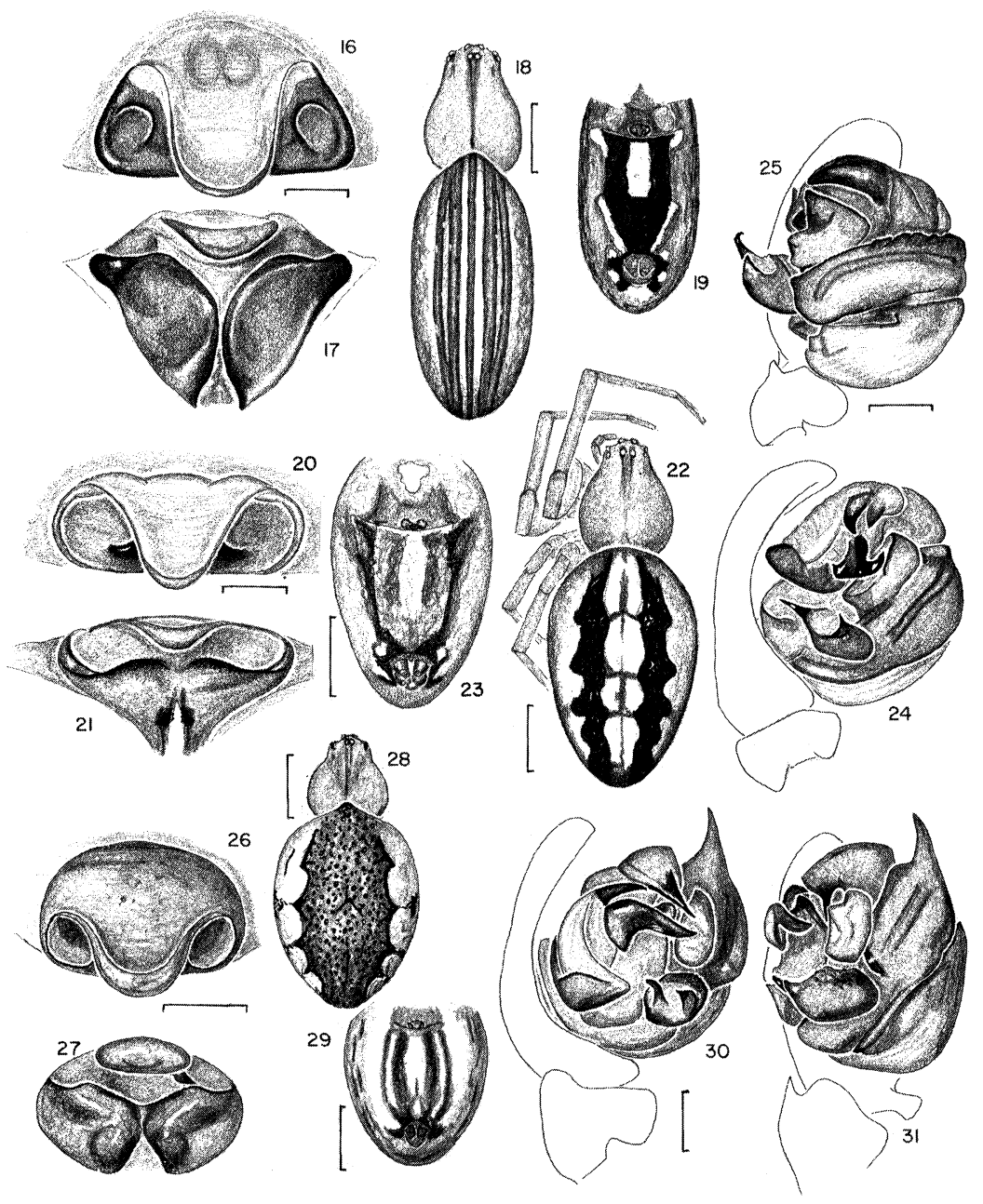

Figures 16-19, Larinia minor (Bryant), female. 16, epigynum, ventral. 17, epigynum, posterior. 18 , dorsal. 19 , abdomen, ventral.

Figures 20-25, Larinia bivittata Keyserling. 20-23, female. 20, epigynum, ventral. 21 , epigynum, posterior. 22 , dorsal. 23 , abdomen, ventral. 24,25 , male. 24 , left palpus, mesal. 25, palpus, ventral.

Figures 26-31, Larinia ambo n. sp. 26-29, female. 26, epigynum, ventral. 27, epigynum, posterior. 28 , dorsal. 29 , abdomen, ventral. 30,31 , male. 30 , palpus, mesal. 31, palpus, ventral. Scale lines, $1.0 \mathrm{~mm}$, genitalia $0.1 \mathrm{~mm}$. 


\section{Larinia bivittata Keyserling}

Figures 20-25; Map 2

Larinia bivittata Keyserling, 1884: 526, pl. 13, fig. 25, ㅇ. Roewer, 1942: 771. Bonnet, 1957: 2348. Female holotype from Maldonado, Brazil [sic Uruguay], in MCZ, examined.

Larinia antarctica Simon, 1905:10. Female holotype from Patagonia, Argentina, in MNHN, examined. Roewer, 1942: 771. Bonnet, 1957: 2347. NEW SYNONYMY.

Epeira lintearia Keyserling, 1893: 236, pl. 11, fig. 176, ㅇ. Female holotype from Rio Grande do Sul, Brazil, in BMNH, examined. NEW SYNONYMY.

Description. Female holotype. Carapace, sternum, legs yellow. Posterior median eyes on black spots with a line going posteriorly which fuses and becomes indistinct. Dorsum of abdomen with two black bands, white in between, and white to sides (Fig. 22); venter between epigynum and spinnerets white, enclosing a pair of longitudinal spots on each side. A narrow black longitudinal band is to the side of the white area. Anterior of spinnerets black (Fig. 23). Posterior median eyes 1.2 diameters of anterior medians, laterals 0.8 diameter of anterior median eyes. Anterior median eyes 1.2 diameters apart. Posterior median eyes their radius apart. Abdomen oval, without prominent anterior tubercle, about 1.5 times as long as wide (Fig. 22). Total length $5.5 \mathrm{~mm}$. Carapace $1.9 \mathrm{~mm}$ long, 1.5 wide. First femur $1.9 \mathrm{~mm}$, patella and tibia 2.6, metatarsus 1.9, tarsus 0.7 . Second patella and tibia $2.3 \mathrm{~mm}$, third 1.4, fourth 2.0 .

Male from Concepción Province, Chile. Color as in female. Posterior median eyes 0.8 diameter of anterior medians, anterior laterals 0.8 diameter, posterior laterals 0.6. Anterior median eyes their diameter apart. Posterior median eyes their radius apart. Total length $3.2 \mathrm{~mm}$. Carapace $1.4 \mathrm{~mm}$ long, $1.3 \mathrm{~mm}$ wide. First femur 1.9 $\mathrm{mm}$, patella and tibia 2.0 , metatarsus, 1.9 , tarsus 0.9 . Second patella and tibia $2.0 \mathrm{~mm}$, third 0.9 , fourth 1.7 .

Illustration. A female from Brazil and a male from Vacaría, Rio Grande do Sul, Brazil were illustrated.

Note. Males and females have been collected together.

Variation. Females varied in total length between 5.2 and 7.2 $\mathrm{mm}$; males between 2.8 and $3.3 \mathrm{~mm}$.

Diagnosis. L. bivittata differs from L. tucuman in the epigynum, which has a posterior lip on each side of the scape that is swollen, dark, and sclerotized (Figs. 20, 21), and in the dark, sclerotized, anchor-shaped embolus of the palpus (Fig. 24). 
Distribution. Southern Brazil, Chile, Paraguay, Uruguay, and Argentina.

Records. BRAZIL Paraná: San Luiz do Puruma (MZSP). Rio Grande do Sul: Bom Jesus; Cambará do Sul; Santa Cruz do Sol; Rio Grande; Santa Vitoría do Palmar, Vacaria (all MCN); Pelotas (AMNH). URUGUAY Maldonado: Piriápolis (CAS). PARAGUAY Transchaco $\mathrm{km} 78$ (IRSNB). ARGENTINA Mendoza: between Mendoza and el Huecu (MCZ). Neuquén: Zapala (MACN). Tucuman: Tafí del Valle (AMNH). Buenos Aires: Capilla del Señor; Castellar (both MLP); Florencio Varelo; Isla Martín García (both MACN); La Plata (MNRJ); 4 km E Zubiaurre (ZMK). Chubut: El Maitén (AMNH). CHILE Antofagasta: Antofagasta (IRSNB). Atacama: Huasco (AMNH). Coquimbo: Ovalle (CAS); Herradura Bay; Loma de Peñueles; Fundo Tahuinco (all AMNH), Hacienda Illapel (IRSNB). Valparaíso: Quintero (AMNH). Santiago: Antumapu (MCZ); El Salto; Lampa; Pudahuel; Quilicura (all AMNH); Santiago (USNM). Maule: Cayurranguil, W of Cauquenes (AMNH). Curicó: Curicó (MCZ). Linares: Fundo Malcho (MCZ), Linares (IRSNB). Nuble: San Carlos (CAS). Concepción: Escuadrón; Desembocadura, Río Bío-Bío; Lenga (all AMNH); Estero Lenga; Nonguen (both MCZ). Arauco: Carampangue (MCZ). Bío-Bío: Caledonia, E of Mulchen (AMNH). Malleco: Nahuelbuta National Park; Selva Oscura W of Curacautín (both AMNH). Cautín: Chacamo, NW of Nueva Imperial and W of Temuco (AMNH); Los Pinos near Loncoche (AMNH); Villarrica (MCZ). Valdivia: Huachocopihue; Isla Teja (both MCZ); Purolón, NW of Panguipulli (AMNH). Osorno: Osorno (AMNH); Termas de Puyehue (MCZ). Chiloé: Dalcahue (IRSNB). Lìanquihue: Carelmapu (IRSNB); Hornohuinca; Petrohué (both MCZ).

\section{Larinia ambo new species}

Figures 26-31; Map 2

Holotype. Female holotype from Ambo, Huánuco Province, 2100 m., Peru (W. Weyrauch), in AMNH. The specific name is a noun in apposition after the type locality.

Description. Female holotype. Carapace light brown with gray margins and median line. Chelicerae, coxae, legs yellow. Labium, sternum, endites black. Dorsum of abdomen with a broad black toothed median band, bordered laterally by white (Fig. 28); venter 
with central white patch and two pairs of brown bands which run from book lungs to spinnerets (Fig. 29). Posterior median eyes, lateral eyes same diameter as anterior medians. Anterior median eyes 1.5 diameters apart. Posterior median eyes 0.6 diameters apart. Abdomen oval, about 1.5 times as long as wide, with small anterior median tubercle (Fig. 28). Total length $4.3 \mathrm{~mm}$. Carapace $1.6 \mathrm{~mm}$ long, 1.3 wide. First femur $2.0 \mathrm{~mm}$, patella and tibia 2.2, metatarsus 1.7 , tarsus 0.8 . Second patella and tibia $2.1 \mathrm{~mm}$, third 1.1, fourth 1.8 .

Male paratype. Color as in female. Posterior median eyes and anterior laterals the same diameter as anterior medians. Posterior laterals 0.8 the diameter of the anterior median eyes. Anterior median eyes 1.5 diameters apart. Posterior median eyes 0.5 diameter apart. Abdomen similar in shape to that of female. Total length 3.0 $\mathrm{mm}$. Carapace $1.5 \mathrm{~mm}$ long, 1.1 wide. First femur $1.7 \mathrm{~mm}$, patella and tibia 2.0 , metatarsus 1.7 , tarsus 0.9 . Second patella and tibia 1.9 $\mathrm{mm}$, third 0.9 , fourth 1.7 .

Illustration. The female holotype and a male from Cerro Portachuelo were illustrated.

Note. Males and females have been collected together.

Variation. Five females varied between 4.1 and $5.1 \mathrm{~mm}$ in length. Two males were 3.0 and $3.3 \mathrm{~mm}$ in length.

Diagnosis. The species differs from others in having a single dark toothed median band on the dorsum of the abdomen (Fig. 28). Males have a distinctive comma-shaped embolus (Fig. 30).

Paratypes. ECUADOR Azuay: Cuenca, 3-14 March 1965, ô (L. Peña, MCZ). PERU Lambayeque: Cerro Portachuelo, nr. Cerro Racaruma, Chongoyape, $0.6^{\circ} 40^{\prime}, 78^{\circ} 28^{\prime}, 450-550 \mathrm{~m}$., 우, $\hat{o}$ (CAS). Huánuco: Ambo, 3ㅇ, $1 \hat{\sigma}$ (W. Weyrauch, AMNH).

\section{Larinia neblina new species}

Figures 32-35; Map 2

Holotype. Female holotype from Cerro de La Neblina, Territorio Federal Amazonas, Venezuela, $0^{\circ} 50^{\prime} \mathrm{N}, 65^{\circ} 59^{\prime} \mathrm{W}, 2100 \mathrm{~m} ., 30$ January 1985 (W. E. Steiner), in USNM. The specific name is a noun in apposition after the type locality.

Description. Female holotype. Carapace, chelicerae, coxae, legs yellow. Sternum yellow, grading into brown along borders. Dorsum of abdomen white, with a narrow brown median band and a pair of 
broader lateral brown bands (Fig. 34); venter with square white patch within brown region (Fig. 35). Posterior median eyes same diameter as anterior medians, laterals 0.7 diameter. Anterior median eyes 1.6 diameters apart. Posterior median eyes 0.7 diameters apart. Abdomen oval, without anterior tubercle, less than 1.5 times as long as wide (Fig. 34). Total length $4.2 \mathrm{~mm}$. Carapace 1.7 $\mathrm{mm}$ long, 1.5 wide. First femur $2.0 \mathrm{~mm}$, patella and tibia 2.5 , metatarsus 1.9, tarsus 0.8 . Second patella and tibia $2.2 \mathrm{~mm}$, third 1.2 , fourth 2.0 .

Natural History. Type specimen was found "on Bennetia and other low shrubs around bog."

Diagnosis. Females differ from other species in having an elongate, transversely striated, distally pointed scape with parallel sides (Fig. 32). (The epigynum contains parts of the male palpus which are impossible to remove, found in the depression on either side of the scape.)

\section{Larinia t-notata (Tullgren)}

Figures 36-42; Map 2

Chrysometa t-notata Tullgren 1905: 28, pl. 3, fig. 8 a, b, ․ Female holotype from Quinta, Jujuy Prov., Argentna, in NRMS, examined. Roewer, 1942: 914. Bonnet, 1956: 1083.

Larinia t-notata - Levi, 1986: 102

Description. Female holotype. Carapace, sternum, legs golden yellow. Abdomen with dorsal longitudinal gray marks (Fig. 38); venter black with median white longitudinal band (Fig. 39). Posterior median eyes subequal to anterior medians, anterior laterals 0.9 diameter, posterior laterals 0.8 diameters of anterior median eyes. Anterior median eyes 1.2 diameters apart, the same distance from laterals. Posterior median eyes 0.7 diameters apart, 2 diameters from laterals. The height of the clypeus is equal to the diameter of the anterior median eyes. The abdomen is almost three times as long as wide, with an anterior median tubercle (Fig. 38). The abdomen is partly destroyed from having been dry. Total length $6.0 \mathrm{~mm}$. Carapace $2.5 \mathrm{~mm}$ long, 1.9 wide. First femur $2.8 \mathrm{~mm}$, patella and tibia 4.0, metatarsus 2.6, tarsus 1.2. Second patella and tibia $3.6 \mathrm{~mm}$, third 2.0, fourth 3.5 .

Male from Pinhal, Est. Santa Catarina, Brazil. Color as in female. Posterior median eyes 1.2 diameters of anterior medians, anterior laterals 0.8 diameter, posterior laterals 0.8. Anterior 
median eyes 1.5 diameters apart. Posterior median eyes 0.2 diameter apart. Total length $6.2 \mathrm{~mm}$. Carapace $3.0 \mathrm{~mm}$ long, 1.2 wide. First femur $3.5 \mathrm{~mm}$, patella and tibia 5.4, metatarsus 4.7, tarsus 1.6. Second patella and tibia $4.6 \mathrm{~mm}$, third 2.3, fourth 4.0 .

Illustration. A female and male from Pinhal, Brazil were illustrated.

Note. Males and females have been collected together.

Variation. Females varied in total length between $6.0 \mathrm{~mm}$ and $8.7 \mathrm{~mm}$. Four males ranged between 5.3 and $6.6 \mathrm{~mm}$.

Diagnosis. L.t-notata differs from other species in the elongate, transversely striated, distally blunt, and often asymetrical scape (Fig. 36), and in the sclerotized, serrated borders of both the tegulum and median apophysis of the palpus (Fig. 40-42).

Distribution. Southern Brazil to Buenos Aires Province, Argentina.

Records. BRAZIL São Paulo: Boracéia, 22-23 Feb. 1961, 2 9 (P. Biasi, MZSP); Camino de Mar, $33 \mathrm{~km} \mathrm{~S} \mathrm{of} \mathrm{São} \mathrm{Paulo,} 11$ Apr. 1965, o (H. Levi and P. Biasi, MCZ); Cocaia - Reprêsa Nova, Sept. 1949, ㅇ (H. Urban, MZSP no. 10109); Fazenda Intervales, $15 \mathrm{~km}$ E. Guapiara, 700 m., Feb. 1990, o (W. Eberhard, MCZ). Santa Catarina: Joaçaba, Jan.-Feb. 1965, ô (L. Bettio, MZSP); Pinhal, Apr.

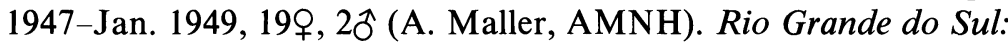
Campo Bom, 3 June 1985, ㅇ (C. J. Becker, MCN 13343); Sertão de Santana, Guaíba, 25 Jan. 1977, ô (A. A. Lise, MCN 4969); Guaíba, 3 Jan. 1974, ô (A. A. Lise, MCN 331); Passo Fundo, 1 Aug. 1986, $+\hat{o}$ (A. A. Lise, MCN 15871); ARGENTINA Santa Fe: Piquete, 1947, o (MLP). Buenos Aires: Parana de las Palmas y Canal 6, 19 Aug. 1963, ô (M. E. Galiano, MEG).

Larinia montecarlo (Levi), new combination Figures 43-48; Map 2

Alpaida montecarlo Levi, 1988: 414, figs. 172-174, Map 3, ․ Female holotype from Montecarlo, Misiones Prov., Argentina, in MACN.

Description. Female from Parque Estadual do Tenente Portela, Rio Grande do Sul, Brazil. Carapace, chelicerae, coxae, legs yellow. Sternum light brown. Dorsum of abdomen white, with a pair of faint grayish lateral bands and a pair of lateral rows of four black dots (Fig. 45). Venter white (Fig. 46). Posterior median eyes 1.3 

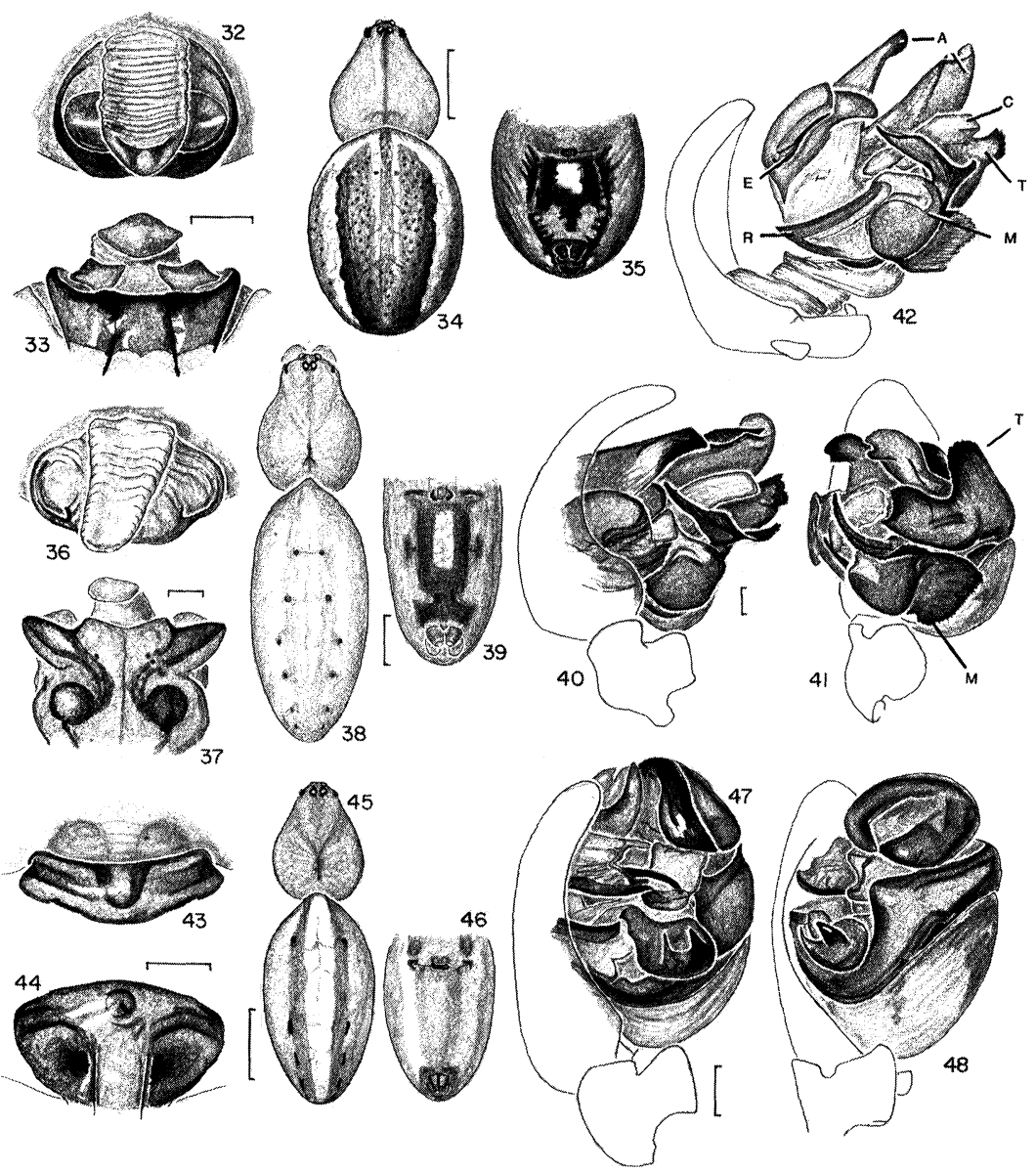

Figures 32-35, Larinia neblina $\mathrm{n}$. sp., female. 32, epigynum, ventral. 33, epigynum, posterior. 34 , dorsal. 35 , abdomen, ventral.

Figures 36-42, Larinia t-notata (Tullgren). 36-39, female. 36, epigynum, ventral. 37, epigynum, posterior. 38 , dorsal. 39 , abdomen, ventral. $40-42$, male. 40 , left palpus, mesal. 41 , palpus, ventral. 42 , palpus, pulled apart.

Figures 43-48, Larinia montecarlo (Levi). 43-46, female. 43, epigynum, ventral. 44, epigynum, posterior. 45 , dorsal. 46 , abdomen, ventral. 47,48 , male. 47 , palpus, mesal. 48, palpus, ventral. Abbreviations. A, terminal apophysis; C, conductor; E, embolus; M, median apophysis; R, radix; T, tegulum. Scale lines, 1.0 $\mathrm{mm}$, genitalia $0.1 \mathrm{~mm}$. 
diameters of anterior medians, laterals 0.8 diameter. Anterior median eyes 2 diameters apart. Posterior median eyes 1.5 diameters apart. Abdomen oval, a little more than twice as long as wide (Fig. 45). Total length $4.5 \mathrm{~mm}$. Carapace $1.7 \mathrm{~mm}$ long, 1.3 wide. First femur $2.5 \mathrm{~mm}$, patella and tibia 3.2, metatarsus 2.9, tarsus 1.1. Second patella and tibia $2.7 \mathrm{~mm}$, third 1.2, fourth 2.0.

Male from Jundiaí, Est. São Paulo, Brazil. Color as in female. Posterior median eyes 1.5 diameter of anterior medians, laterals 0.8 diameters. Anterior median eyes 2 diameters apart. Posterior median eyes 1 diameter apart. Abdomen similar in shape to that of female. Total length $4.0 \mathrm{~mm}$. Carapace $2.0 \mathrm{~mm}$ long, 1.5 wide. First femur $2.5 \mathrm{~mm}$, patella and tibia 3.2, metatarsus 3.0, tarsus 1.1. Second patella and tibia $2.7 \mathrm{~mm}$, third 1.4 , fourth 2.5 .

Illustration. A female from Tenente Portela and a male from Triunfo were illustrated.

Variation. Nine females varied in total length between 4.4 and $5.5 \mathrm{~mm}$ long. Males varied between 4.0 and $4.3 \mathrm{~mm}$ long.

Note. Males and females were collected together.

Diagnosis. L. montecarlo differs from other Larinia in lacking an epigynal scape (Fig. 43) and in the configuration of the male palpus (Fig. 47).

Records. BRAZIL São Paulo: Jundiaí, 1-15 June 1976, ô (A. Schneble, MCZ). Paraná: Curitiba, 2 Nov. 1987, ㅇ (A. D. Brescovit, MCN 17158). Santa Catarina: Araranguá, 18 Feb. 1985, ㅇ (A. D. Brescovit, MCN 13149). Rio Grande do Sul: Linha Alegre, Arroio do Meio, 9 Jan. 1985, (A. D. Brescovit, MCN 12899); São Valentim, 16 Oct. 1976, \& (S. Scherer, MCN 4703); Parque Estadual do Tenente Portela, 29 Nov. 1978, 15 Jan. 1985, 2o, ồ (H. Bischoff, A.

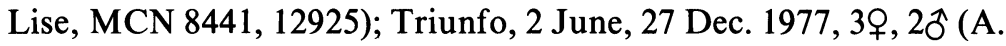
Lise, H. Bischoff, MCN 5672, 7035), Nonoai, 14 Jan. 1985, ô (A. A. Lise, MCN no. 12820).

\section{Literature Cited}

BANKS, N.

1898. Arachnida from Baja California and other parts of Mexico. Proc. California Acad. Sci. 1: 205-308.

BONNET, P.

1956. Bibliographia Araneorum. Toulouse, Douladore, 2: 919-1926.

1957. Bibliographia Araneorum. Toulouse, Douladore, 3: 1927-3026. 
Brignoli, P. M.

1983. A catalogue of the Araneae described between 1940 and 1981. Manchester University Press. 1-775.

Bryant, E. B.

1942. Additions to the spider fauna of Puerto Rico. J. Agric. Univ. Puerto Rico, 26: 1-16.

1945. The Argiopidae of Hispaniola. Bull. Mus. Comp. Zool. 95: 357-418.

Cambridge, F. P.

1903. Arachnida, Araneidea, and Opiliones 2: 1-608. In Biologia CentraliAmericana, Zoologia, London.

Cambridge, O. P.

1889. Arachnida, Araneidea 1: 1-309. In Biologia Centrali-Americana, Zoologia, London.

CAPORIACCO, L., di

1955. Estudios sobre los Arachnidos de Venezuela. Acta Biologica Venezuelica, Universidad Central, 1: 265-448.

Chamberlin, R. V.

1924. The spider fauna of the shores and islands of the Gulf of California. Proc. California Acad. Sci. 12: 561-694.

Comstock, J. H.

1913. The Spider Book. Doubleday, Garden City, New York.

Franganillo, B.

1934. Aráchnidos cubanos estudiados desde 1930 hasta 1934. Mem. Soc. Cubana. Hist. Nat. 8: 145-168.

GrasshofF, M.

1970a. Die Gattung Kilima n.gen. (Arachnida: Araneae: Araneidae-Araneinae). Senckenberg. Biol. 51(1/2): 119-128.

1970b. Die Tribus Mangorini. I. Die Gattungen Eustala, Larinia s.str., Larinopa n.gen. (Arachnida: Araneae: Araneidae-Araneinae). Senckenberg. Biol. 51(3/4): 209-234.

1970c. Die Tribus Mangorini. II. Die Neuen Gattungen Siwa, Paralarinia, Faradja, Mahembea, und Lariniaria (Arachnida: Araneae: AraneidaeAraneinae). Senckenberg. Biol. 51(5/6): 409-423.

1971. Die Tribus Mangorini. III. Die Gattung Drexelia MacCook (Arachnida: Araneae: Araneidae-Araneinae). Senckenberg. Biol. 52(1/2): 81-95.

Hentz, N. M.

1847. Descriptions and figures of the Araneides of the United States. Boston Jour. of Natur. Hist. 5: 443-478.

Keyserling, E.

1880. Neue Spinnen aus Amerika. Verhandl. zool. bot. Gesellsch. Wien. 29: 293-349.

1884. Neue Spinnen aus Amerika. Verhandl. zool. bot. Gesellsch. Wien. 34: 489-534.

1892. Die Spinnen Amerikas, Epeiridae, Nürnburg, vol. 4(1): 1-208.

1893. Die Spinnen Amerikas, Epeiridae, Nürnburg, vol. 4(2): 209-377.

LEVI, H. W.

1968. The spider genera Gea and Argiope in America (Araneae: Araneidae). 
Bull. Mus. Comp. Zool. 136(9): 319-252.

1971. The Ravilla group of the orb-weaver genus Eriophora in North America (Araneae: Araneidae). Psyche 77(3): 280-302.

1974. The orb-weaver genus Zygiella (Araneae: Araneidae). Bull. Mus. Comp. Zool. 146(5): 267-290.

1975. The American orb-weaver genera Larinia, Cercidia, and Mangora (Araneae: Araneidae) north of Mexico. Bull. Mus. Comp. Zool. 147(3): 101-135.

1977. The American orb-weaver genera Cyclosa, Metazygia and Eustala north of Mexico (Araneae: Araneidae). Bull. Mus. Comp. Zool. 148(3): 61-127.

1985. The spiny orb-weaver genera Micrathena and Chaetacis (Araneae: Araneidae). Bull. Mus. Comp. Zool. 150(8): 429-615.

1986. The neotropical orb-weaver general Chrysometa and Homalometa (Araneae: Tetragnathidae). Bull. Mus. Comp. Zool. 151(3): 91-215.

1988. The Neotropical orb-weaving spiders of the genus Alpaida (Araneae: Araneidae). Bull. Mus. Comp. Zool. 151(7): 365-487.

1989a. The neotropical orb-weaver genera Epeiroides, Bertrana and Amazonepeira (Araneae: Araneidae). Psyche 96: 75-99.

1989b. Key to the neotropical genera of Araneidae. Personally distributed key available directly from $\mathrm{H}$. W. Levi.

in press. The neotropical and Mexican species of the orb-weaver genera Araneus, Dubiepeira and Aculepeira (Araneae: Araneidae). Bull. Mus. Comp. Zool.

LEVY, G.

1986. Spiders of the genera Siwa, Larinia, Lipocrea, and Drexelia (Araneae: Araneidae) from Israel. Bull. Brit. Arachnol. Soc. 7(1): 1-10.

LuCAS, $\mathrm{H}$.

1846. Histoire naturelle des Animaux articulés. Paris.

MARUSIK, Y. M.

1986. The orb-weaver genus Larinia Simon in the USSR. Spixiana 9: 245-254. МсСоок, H. C.

1892. Drexelia, a new genus of spiders. Proc. Acad. Nat. Sci. Philad. 1892: 127.

MeLlo-Leitão, C. DE

1940. Aranhas do Espirito Santo. Separata dos Arq. de Zool. Est. São Paulo: 199-214.

1944. Arañas de la Provincia de Buenos Aires. Rev. Mus. La Plata 3: 311-393.

1947a. Aranhas do Carmo do Rio Claro. Bol. Mus. Nac. Rio de Janeiro (N. S.) 80: $1-34$.

1947b. Aranhas do Paraná e Santa Catarina, das coleções do Museu Paraense. Archos. Mus. Parana. 6(6): 231-304.

1951. Arañas de Maullin. Rev. Chilena de Hist. Natur.: 327-338.

Petrunkevich, A.

1930. The Spiders of Puerto Rico. Trans. Connecticut Acad. Sci. 30: 159-355. ROEWER, C. F.

1942. Katalog der Araneae, Bremen, vol. 1. 
Simon, E.

1874. Les Arachnides de France, Paris, 1: 1-272.

1905. Etude sur les Arachnides recuellis en Patagonia. Boll. Mus. zool. anat. comp. Torino 20: 1-17.

STRAND, E.

1916. Systematische-faunistische Studien. Arch. Naturg. 81 A: 1-153.

TANIKAWA, A.

1989. Japanese spiders of the genus Larinia Simon (Araneae: Araneidae). Acta Arachnol. 38: 31-47.

Tullgren, A.

1905. Araneida from the Swedish Expedition through the Gran Chaco and the Cordilleras. Ark. Zool. 2: 1-81. 

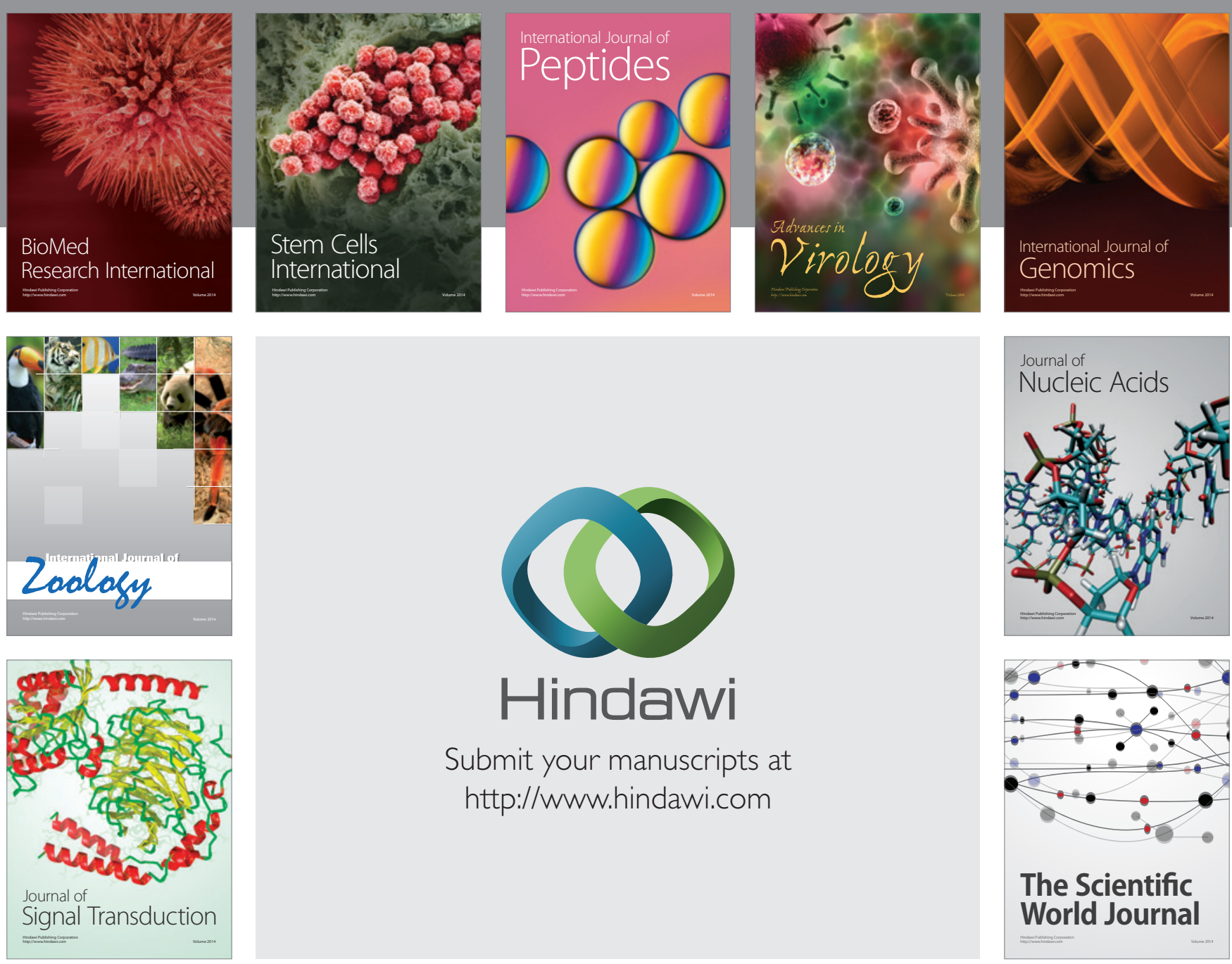

Submit your manuscripts at

http://www.hindawi.com
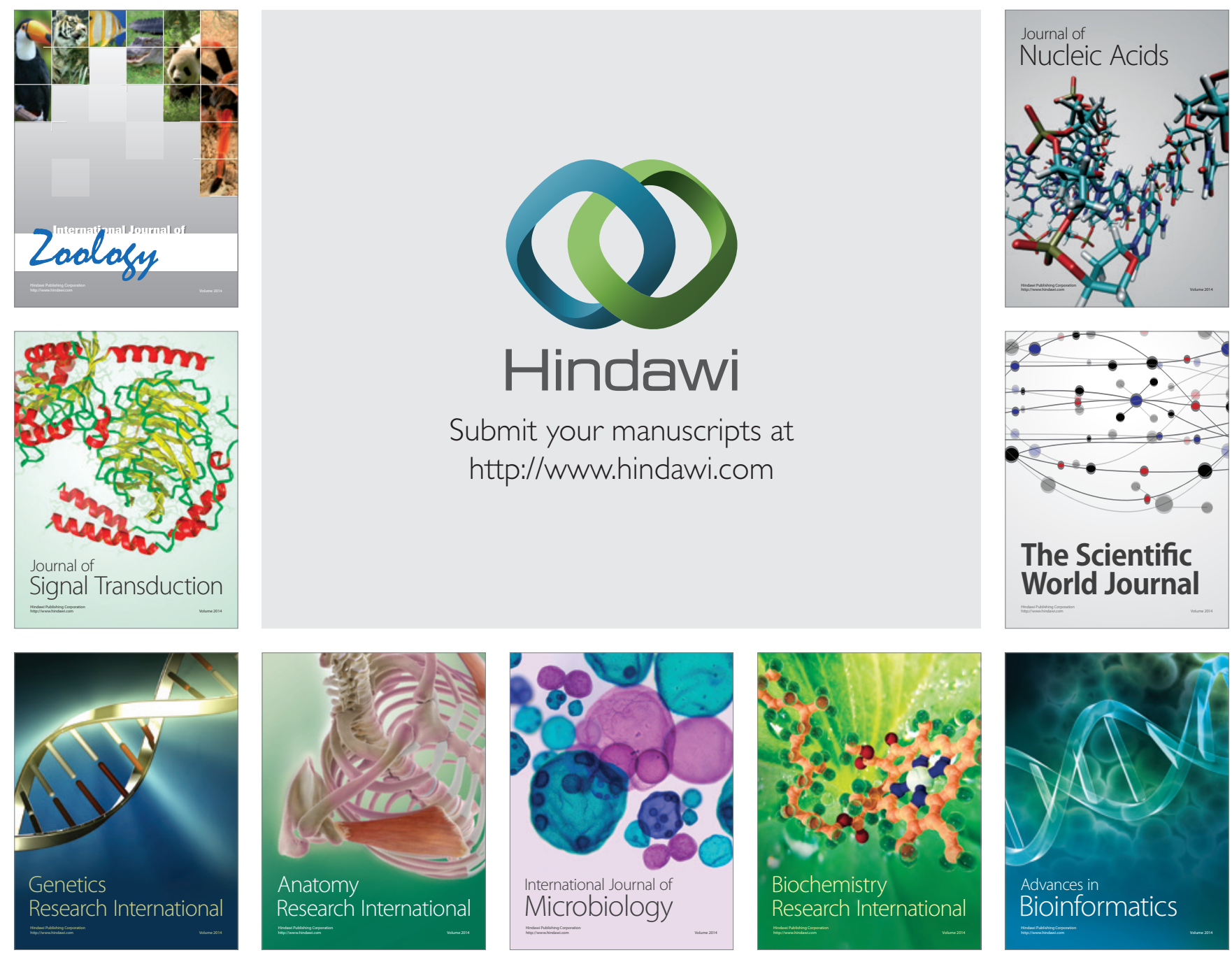

The Scientific World Journal
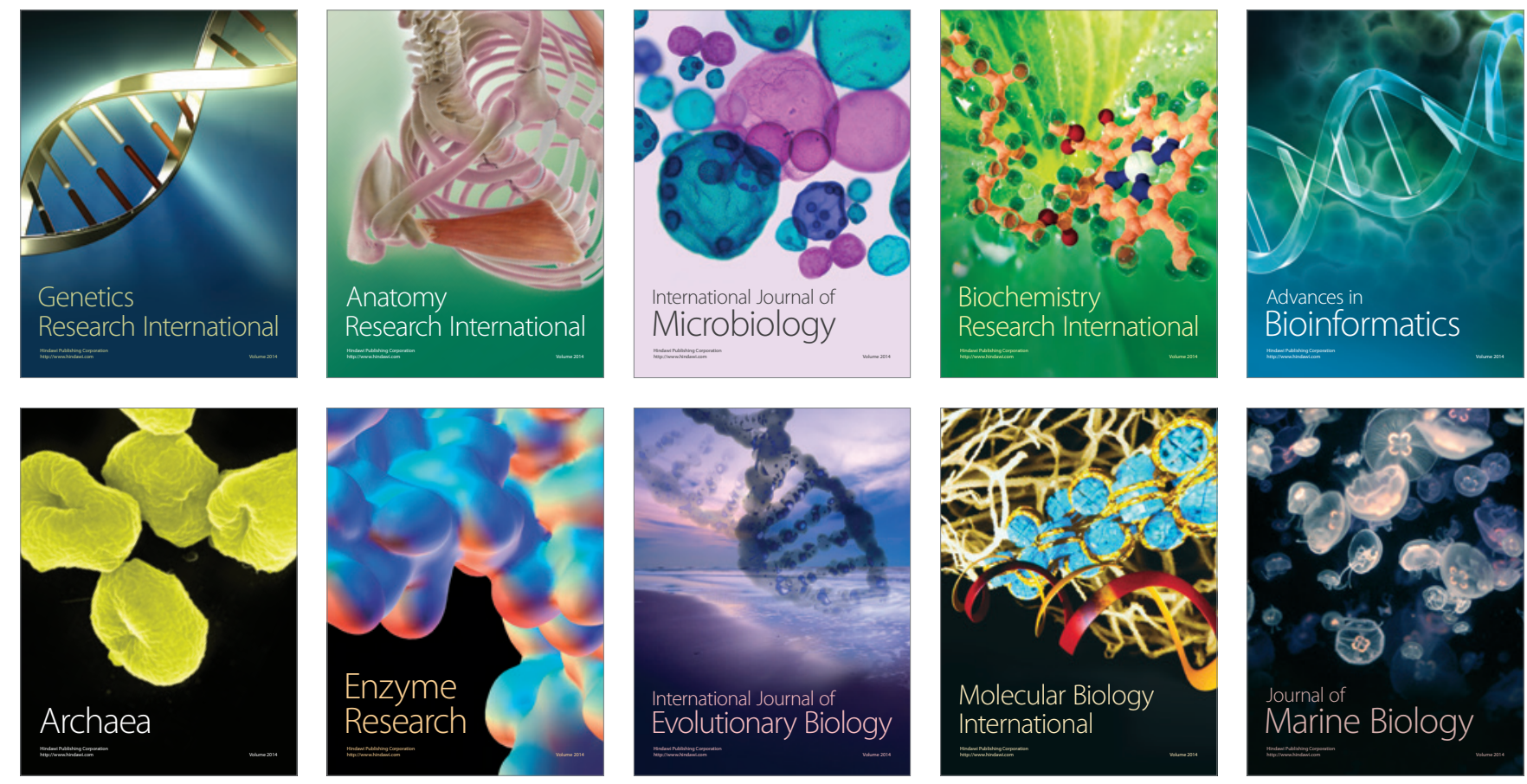